\title{
PoPUlation STRUCTURE AND ONE-YEAR DYNAMICS OF THE ENDANGERED TROPICAL TREE SPECIES CAESALPINIA ECHINATA LAM. (BRAZILIAN RED-WOOD): THE POTENTIAL IMPORTANCE OF SMALL FRAGMENTS FOR CONSERVATION
}

\author{
Pablo José Francisco Pena Rodrigues ${ }^{1,2}$, Rodolfo Cesar Real de Abreu ${ }^{2}$, \\ Eduardo M. B. Barcellos ${ }^{1}$, Haroldo Cavalcante de Lima ${ }^{2}$ \\ \& Fabio Rubio Scarano ${ }^{1,2,3}$
}

\begin{abstract}
(Population structure and one-year dynamics of the endangered tropical tree species Caesalpinia echinata Lam. (Brazilian red-wood): the potential importance of small fragments for conservation) Caesalpinia echinata Lam. an endangered species, occurs in forest fragments of the Cabo Frio region, in Rio de Janeiro, Brazil. Data from four sub-populations were used to describe local population patterns and one-year dynamics. In each subpopulation, 0.1 ha-plots were set up and all C. echinata trees were mapped, and diameter and height were measured. The fragments sampled had different sizes and were subjected to various degrees of man-made disturbance, representing a succession gradient from an earlier (small fragment) to a later stage (large fragment). We compared the sub-populations as regards density, size structure, spatial distribution, germination and mortality, to identify short-term responses to mechanical injuries (broken stems, sand burial and man-made cuts). Matrix analysis considering the four $C$. echinata sub-populations together showed a slight tendency for population expansion $(\lambda=1.0211)$ if injury patterns do not lead to habitat extinction. On the other hand, sub-populations showed aggregated distribution patterns, particularly at forest edges. Diameter size structure varied from a reversed-J pattern, i.e. seedling abundance in the small fragment (more impacted sub-population) to a uniform plant distribution of size classes in the large one (less impacted sub-population). The sub-population in the smallest fragment showed the highest birth and mortality, in contrast to reduced demographic variation in the largest fragment. Moreover, the smallest fragment also showed the largest seedling stand density and biomass. These data indicate the potential importance of small fragments for the conservation of the Brazilian red-wood.
\end{abstract} Key words: Atlantic forest, Cabo Frio region, fragmentation, population structure, matrix analysis.

\section{Resumo}

(Estrutura populacional e dinâmica de um ano da espécie ameaçada Caesalpinia echinata Lam. (pau-brasil): a importância potencial de pequenos fragmentos para conservação) Caesalpinia echinata Lam. (pau-brasil) é uma espécie ameaçada de extinção que ocorre em fragmentos florestais da região de Cabo Frio no Rio de Janeiro. Quatro sub-populações da região foram utilizadas para deteçcão de padrões populacionais e estudo de um ano de dinâmica da espécie. Em cada uma destas sub-populações, parcelas de 0,1 ha foram estabelecidas e todos os indivíduos de $C$. echinata foram mensurados quanto ao diâmetro e altura. Os fragmentos selecionados possuíam tamanhos distintos e estavam sujeitos a impactos antropogênicos diferenciados. Tais impactos representaram gradientes de sucessão de estágios iniciais (fragmento pequeno) até estágios tardios (fragmento grande). As sub-populações foram comparadas quanto à densidade de indivíduos, estrutura de tamanhos, distribuição espacial, germinação e mortalidade, a fim de detectar respostas em curto-prazo das plantas aos danos mecânicos (quebra, soterramento e corte). Análises de Modelos Matriciais foram realizadas considerando as quatro sub-populações como uma única população local. Estas indicaram pequena tendência de expansão populacional após eventos reprodutivos $(\lambda=1,0211)$, caso os padrões de danos não conduzissem a extinção total do habitat. Paralelamente, as sub-populações exibiram padrões agregados de distribuição, especialmente nas bordas florestais. A estrutura de diâmetros variou desde o padrão de J-reverso, e.g. abundância de sementes no fragmento pequeno (sub-população mais impactada) até a distribuição uniforme observada nas classes de diâmetros do maior fragmento (sub-população menos impactada). A sub-população do menor fragmento exibiu as maiores taxas de nascimento e mortalidade, contrastando com a reduzida variação demográfica do maior fragmento. Entretanto, o menor fragmento também exibiu a maior densidade de plântulas e biomassa. Estes resultados indicam que pequenos fragmentos também são importantes para a conservação do pau-brasil.

Palavras-chave: Mata Atlântica, Cabo Frio, fragmentação, estrutura de populações, modelos matriciais.

Artigo recebido em 05/2008. Aceito para publicação em 02/2009.

${ }^{1}$ Universidade Federal do Rio de Janeiro, Dep. Ecologia, IB, CCS, C.P. 68020, 21941-970, Rio de Janeiro RJ, Brazil. ${ }^{2}$ Instituto de Pesquisas Jardim Botânico do Rio de Janeiro, R. Pacheco Leão 915, 22460-030, Rio de Janeiro, RJ, Brazil.

${ }^{3}$ Autor para correspondência: fscarano@biologia.ufrj.br 


\section{INTRODUCTION}

Increasing forest fragmentation creates even more small fragments, which often modify species distribution and abundance (Laurance et al. 1998; Fahrig 2003; Harper et al.2005). For instance, the smaller the fragment the worse the deleterious edge effect (Janzen 1983; Laurance 2000). Among the most reported consequences are decline in seedlings of shade-tolerant species (Benitez-Malvido 1998) and biomass (Laurance et al. 1997), and changes in vegetation structure (Didham \& Lawton 1999; Williams-Linera 1990; Laurance et al. 2001) and dynamics (Oliveira-Filho et al. 1997; Laurance et al. 2002, 2007). Since species populations often consist of series of sub- or local populations with a naturally fragmented distribution (Hanski \& Gilpin 1991), habitat fragmentation and loss are further divisive forces that contribute to the decline of population density and lead to species extinction (Sih et al. 2000).

However, species can respond in different ways to man-induced environmental changes and a variety of responses related to mortality and recruitment is cited for distinct types of impact and of biological conditions (Lieberman et al. 1985; Condit et al. 1995; Bruna et al. 2002). Therefore, studies on population dynamics are an important tool for species conservation (Ehrlén \& Groenendael 1998). This type of study often demands long-term efforts, particularly in the case of long-lived species such as many tropical trees, which is in contrast with the high speed of deforestation many habitats are currently facing (Myers et al. 2000), especially the tropical dry forests (Mooney et al. 1995; Sanchez-Azofeifa et al. 2005).

This is the case of Caesalpinia echinata Lam, a long-lived tropical tree which is rare and extremely threatened with extinction (sensu Schemske et al. 1994) according to Brasil (1992). Some of the last natural remnant populations of the Brazilian southeast are found in the Cabo Frio region in Rio de Janeiro state. This is a very fragmented Centre of Plant Diversity (Araujo 1997) and pointed out as the habitat of the most genetically diverse and preserved C. echinata population in southeastern Brazil (Cardoso et al. 2005). Therefore, longterm studies on population dynamics of this species would be essential for conservation planning. However, the absence of conservation units to protect this species and the still very high deforestation rates, due to land speculation and predatory tourism, call for urgent initiatives and hinder long-term studies. Hence, in this study we tried to identify general population patterns and short-term relationships between damage, local survival and regeneration of the Brazilian red-wood in forest fragments. We use size structure data and one year dynamics from 4 sub-populations in neighbouring sites that represent a gradient from an earlier (small fragment) to a later (large fragment) succession stage (see McCook 1994), due to previous human activity. Our premise is that a shortterm structural study to compare different succession stages within this spatial gradient helps provide an understanding of long-term population dynamics.

\section{Material AND Methods \\ Studied species}

Caesalpinia echinata Lam. (LeguminosaeCaesalpinoideae) is a tree species that can reach heights of up to $10-20 \mathrm{~m}$, rarely $30 \mathrm{~m}$, and is typical of the Brazilian coastal plain forest. It was originally distributed abundantly in seasonal semideciduous vegetation patches, with sclerophyllous appearance, along the Brazilian Atlantic coast between the northeastern state of Rio Grande do Norte and São Paulo state in the southeast. Nowadays, however, only small native populations can be found (Cunha \& Lima 1992).

The Brazilian red-wood has suffered predatory exploitation during the past $500 \mathrm{yrs}$. Its harvest was an important economic activity because of the red colour extract used to tinge clothes (Corrêa 1974). The chemical production of pigments finished this overexploitation, but too late to avoid the near extinction of the species. The tree is currently grown commercially 
in some parts of the country, and the wood is exported for the production of high quality violin bows (Cunha \& Lima 1992).

\section{Study area}

The study area $\left(22^{\circ} 48^{\prime} \mathrm{S}-41^{\circ} 58^{\prime} \mathrm{W}\right)$ is located in the state of Rio de Janeiro between Cabo Frio and Armação de Búzios municipalities (Cabo Frio region). This site is a semideciduous forest where $C$. echinata is among the dominant species (Geßler et al. 2005). This forest is part of the so-called Atlantic forest complex (see Oliveira-Filho \& Fontes 2000; Scarano et al. 2001; Scarano 2002), which has been reduced to less than $7 \%$ of its original area, thus consisting of one of the world's most important biodiversity hotspots (Myers et al. 2000). The climate according to the Köppen system corresponds to a variation of Hot-arid (Bsh) contrasting with the predominantly rainy climate of the rest of the state. Rainfall is around $800 \mathrm{~mm} /$ year, with less than $80 \mathrm{~mm} /$ month. Dry season is from June to August, with ca. $40 \mathrm{~mm} /$ month (FEEMA 1988).

Sub-populations of $C$. echinata were sampled at the following sites: a) a small fragment (SF; ca. 0.2 ha); b) a hillside fragment (HF; ca. 2.5 ha); c) the centre (CF) and d) the edge (EF) of a large fragment (ca. 10 ha). SF lies between an unpaved road and a pasture. The canopy is dominated by a large $C$. echinata tree (ca. $15 \mathrm{~m}$ tall), which provides shade for most of the fragment. However, a pronounced edge effect, in addition to canopy gaps, allows for light penetration in the understory, where climbers occur abundantly. Moreover, trampling by cattle commonly takes place, given that this fragment is not fenced. HF is on a hillside and its canopy reaches ca. $9 \mathrm{~m}$ tall. $\mathrm{CF}$ and $\mathrm{EF}$ are located in a dense, mature, dry forest remnant (ca. $10 \mathrm{ha}$ ) bordered by pastures, occasionally invaded by cattle. CF is a sub-population deep inside (200 $\mathrm{m}$ from the edge) the forest and $\mathrm{EF}$ was at the edge of the forest (from the edge to $30 \mathrm{~m}$ inwards). For structural analysis we considered $\mathrm{CF}$ and $\mathrm{EF}$ as distinct subpopulations due to the absence of individuals of C. echinata between these two groups and the obvious environmental differences between edge and centre of this forest fragment. For dynamic analysis we considered the four subpopulations together. Canopy plants reached ca. $10 \mathrm{~m}$ with emergent ones, like C. echinata, reaching heights of $15 \mathrm{~m}$.

\section{Population sampling and data analyses}

A 0.1 -ha plot $(20 \mathrm{~m} \times 50 \mathrm{~m})$ was established in each sub-population site between June and August 1996. The plots were subdivided into forty $5 \times 5 \mathrm{~m}$ quadrats. Each specimen of C. echinata was labelled, mapped and measured for basal diameter (bd) and height (h). Mechanical injuries, such as broken stems, sand burial, resprouting and man-made cuts, were recorded. After one year, all individuals were measured and observed again. Seedlings germinated in November 1997 (3 months after the 1997 re-sampling) were sampled inside ten $1 \mathrm{~m} \times 1 \mathrm{~m}$ plots randomly placed in a circle (20 m radius) which had at its centre one reproductive adult, at each of the four sub-population sites. Spatial distribution patterns were determined using Morisita's Standardized Dispersion Index (Krebs 1989).

\section{Biological diameter classes}

Basal diameter (bd) classes were defined based on biological characteristics of the plants. Thus, seedling stage 1 (bd $\leq 5 \mathrm{~mm}$ ) showed the first leaves and a thin, brown stem. Seedling stage $2(5 \mathrm{~mm}<\mathrm{bd} \leq 10 \mathrm{~mm})$ had more leaves and a thin stem tending to grey (due to lichen colonization) with small thorns. Sub-saplings $(10 \mathrm{~mm}<\mathrm{bd} \leq 20 \mathrm{~mm})$ and saplings $(20 \mathrm{~mm}<$ bd $\leq 30 \mathrm{~mm}$ ) had thorny, woody stems, grey and with old apical meristem scars. Sub-adults (30 $\mathrm{mm}<$ bd $\leq 60 \mathrm{~mm}$ ) were trees that did not flower during the reproductive season of 1997. Small adults $(60 \mathrm{~mm}<$ bd $\leq 150 \mathrm{~mm})$ were emergent trees that flowered at the hillside fragment. Adults (bd $>150 \mathrm{~mm}$ ) flowered and often occupied the emergent stratum.

The sum of diameters of all individuals in each sub-population was used to obtain the 
basal area $\left(\mathrm{m}^{2}\right)$. One-way analysis of variance was used to assess differences between population size structures in 1997 of seedlings (bd $<20 \mathrm{~mm}$ ), saplings $(20 \mathrm{~mm}<$ bd $\leq 60 \mathrm{~mm}$ ) and adults (bd $>60 \mathrm{~mm}$ ). Spojtvoll/Stoline Tukey's tests were used to compare mean values of these categories (Sokal and Rohlf 1995).

\section{Whole-population patterns}

A transition matrix model as described by Lefkovitch (1965) and modified by Caswell (1989) was used to analyze $C$. echinata population dynamics. All sampled subpopulations were treated here as a unique population, which was a legitimate approach as demonstrated by molecular biology studies (Cardoso et al. 2005). The matrix is of the form: $n_{t+1}=A \times n_{t}$. where $A$ is a square matrix containing transition probabilities among categories during one time-step and $n$ is a vector containing the number of individuals in each category at time $t$ and $t+1$. This equation assumes that environmental factors are constant in time and the population structure at time $t+1$ is obtained by multiplying the structure at time $t$ with the transition matrix that contains information on population dynamics. By repeated multiplication of the transition matrix with a distribution vector of the abundances of the classes, the population growth rate converges asymptotically to a constant that equals the dominant eigenvalue $\lambda$ of the matrix (Caswell 1989). Fecundity was calculated assuming a post-reproductive event as $F=s_{j} x f_{j}$ (Morris \& Doak 2002), where $s_{j}=$ individual survival in class $j$, and $f_{j}=$ number of seedlings divided by number of adults in class $j$. We arbitrary weights from 0.4 for Small Adults and 0.6 for Adults according to their sizes they can contribute in different ways to species reproduction. As there were no transitions for saplings, subadults and small adults to other size classes, minimal artificial transitions of $1 \%$ were introduced in the model to maintain an uninterrupted life-cycle.

\section{Results \\ Sub-population patterns}

C. echinata sub-populations showed aggregated distribution patterns that were most evident on forest edges. The centre of the large fragment $(\mathrm{CF})$ and the small fragment $(\mathrm{SF})$, despite contrasting densities (Fig. 1; Table 3), showed Morisita's Standardized Dispersion Indexes of 0.036 and 0.024 respectively, which indicate at a local scale a tendency to a random distribution pattern. However, the more impacted edge sites (edge of the large fragment, $\mathrm{EF}$, and hillside fragment, HF) showed indexes of ca. 0.2 (highly aggregated), probably due to high seedling densities forming small clumps.

The size structure of the sub-populations was based on frequency distribution of individuals per basal diameter (bd) class and ranged from a reversed-J pattern at the edge sites (SF, HF and EF) to a U-pattern in the centre of the larger fragment (CF), where no saplings were found (Fig. 1). Interestingly, the two edge sites subjected to more man-made impact (SF and $\mathrm{HF}$ ) showed a higher proportional reduction in sapling density than the edge of the less impacted fragment (EF). Similar size structure patterns were found for height (data not shown). Seedlings represented $96.7 \%$ (ca. 800/0.1 ha) of the SF sub-population probably due to the reproductive performance of four local adults that produced ca. 9.0 seedlings $/ \mathrm{m}^{2}$ in November 1997 (Table 2). These adults apparently did not differ in basal diameter (bd) from the adults at other sites (Table 3). However, LF and EF had 13 (maximum bd of $350 \mathrm{~mm}$ and basal area of $0.09 \mathrm{~m}^{2}$ ) and 19 (maximum bd of $382 \mathrm{~mm}$ and basal area of $0.11 \mathrm{~m}^{2}$ ) adults respectively while SF and HF had only 4 (maximum bd of $780 \mathrm{~mm}$ and basal area of $\left.0.40 \mathrm{~m}^{2}\right)$ and $8(181 \mathrm{~mm}$ and $0.02 \mathrm{~m}^{2}$ respectively) adults (Fig. 1). Differences between seedling diameter size classes were marked (Table 3) probably because of the contrasting densities. SF, HF and CF saplings showed similar mean bd.

Plants at the more impacted sites (SF and $\mathrm{HF}$ ) showed several mechanical injuries (Table 1) and SF had the highest proportion of 
Small Fragment (SF)
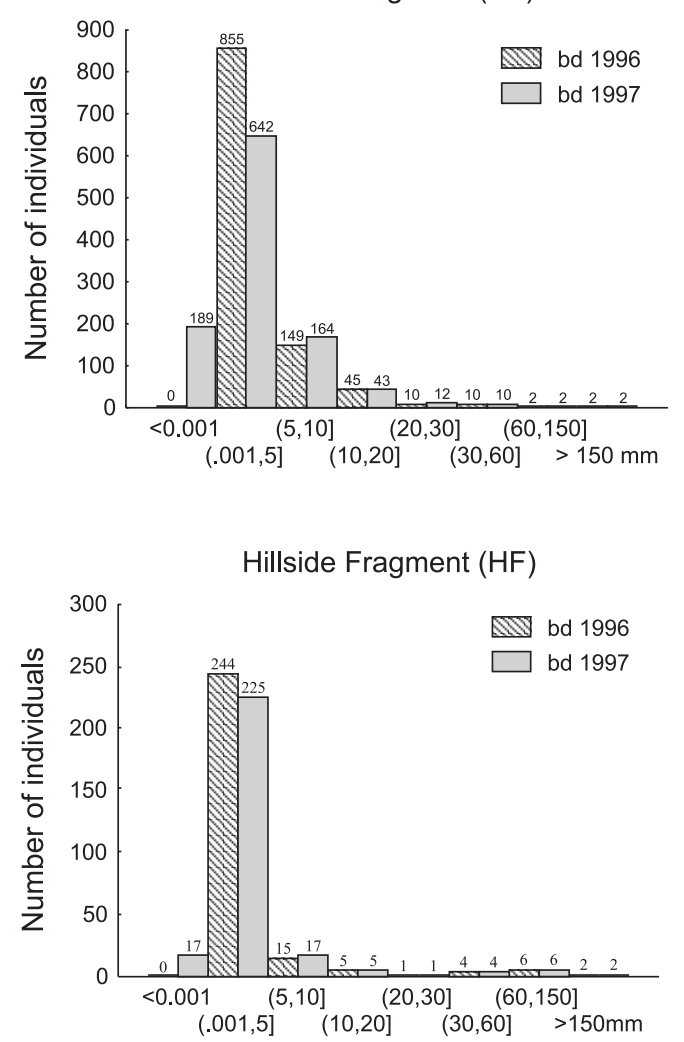

Large Fragment, Edge (EF)

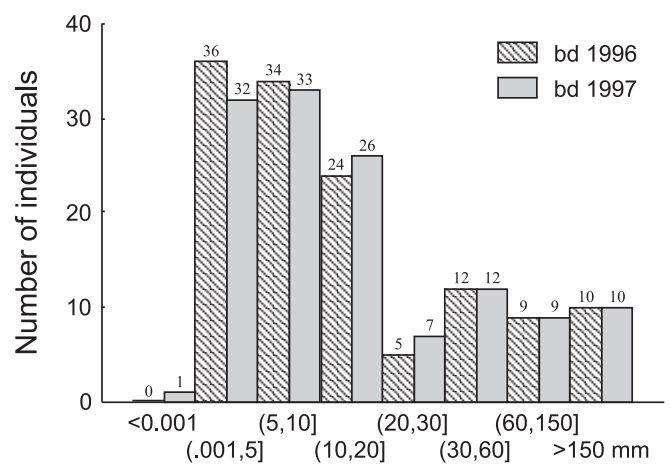

Large Fragment, Centre (CF)

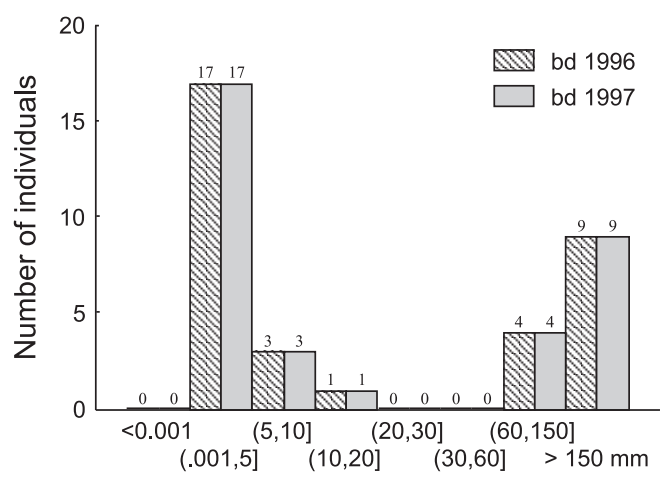

Figure 1 - Frequency distribution of plant basal diameters in sub-populations of C. echinata in four distinct forest fragments: Small Fragment (SF), Hillside Fragment (HF), Large Fragment, Edge (EF) and Large Fragment, Centre (CF).

Table 1 - Number of individuals (n), mortality and summary of mechanical injury in sub-populations of $C$. echinata in four distinct forest fragments at Cabo Frio region: Small Fragment (SF), Hillside Fragment Edge (HF), Large Fragment, Edge (EF) and Large Fragment, Centre (CF).* only seedlings died.

\begin{tabular}{lccccccc}
\hline Site & $\begin{array}{c}\text { n } \\
\mathbf{1 9 9 6}\end{array}$ & $\begin{array}{c}\mathbf{1 9 9 7} \\
\mathbf{1 9 9}\end{array}$ & $\begin{array}{c}\text { Mortality* } \\
(\mathbf{\%}) \mathbf{9 6 / 9 7}\end{array}$ & $\begin{array}{c}\text { Broken Stems } \\
\mathbf{9 6 / 9 7}\end{array}$ & $\begin{array}{c}\text { Sand burial } \\
\mathbf{9 6 / 9 7}\end{array}$ & $\begin{array}{c}\text { Resprouts } \\
\mathbf{1 9 9 6}\end{array}$ & $\begin{array}{c}\text { Man-made } \\
\text { cuts 96/97 }\end{array}$ \\
\hline SF & 1074 & 885 & 17.5 & $87(9.8 \%)$ & $56(6.3 \%)$ & $40(4.5 \%)$ & $1(0.1 \%)$ \\
HF & 277 & 260 & 6.1 & $6(2.3 \%)$ & $2(0.7 \%)$ & 0 & $1(0.3 \%)$ \\
EF & 130 & 129 & 0.7 & $5(3.8 \%)$ & 0 & $6(4.6 \%)$ & $3(2.3 \%)$ \\
CF & 34 & 34 & 0 & $2(5.8 \%)$ & 0 & $2(6.8 \%)$ & 1 \\
\hline
\end{tabular}

Table 2 - Density of C. echinata seedlings germinated in November 1997, after a reproductive event, in four sub-populations at distinct sites at Cabo Frio region.

\begin{tabular}{lcc}
\hline Site & Means \pm SE of seedlings $/ \mathbf{m}^{\mathbf{2}}(\mathbf{n = 1 0})$ & higher $^{\text {density } \text { sample }^{\mathbf{a}}}$ \\
\hline Small Fragment & $9.0 \pm 2.3$ & 24 \\
Hillside Fragment & $0.3 \pm 0.1$ & 1 \\
Large Fragment, Edge & $0.0 \pm 0.0$ & 0 \\
Large Fragment, Centre & $0.1 \pm 0.1$ & 1
\end{tabular}

${ }^{a}$ number of individuals in the sample quadrat $(1 \mathrm{x} 1 \mathrm{~m})$ with higher density 
Table 3 - Mean \pm SE (n) of basal diameters of $C$. echinata seedlings, saplings and adults in four distinct sub-populations at Cabo Frio region: Small Fragment (SF), Hillside Fragment (HF), Large Fragment, Edge (EF) and Large Fragment, Centre (CF).

\begin{tabular}{lllccc}
\hline Size class & \multicolumn{1}{c}{ SF } & \multicolumn{1}{c}{ HF } & \multicolumn{1}{c}{ EF } & CF & \multicolumn{1}{c}{ F } \\
\hline Seedling & $4.2 \pm 0.1(858) \mathrm{a}$ & $3.1 \pm 0.1(246) \mathrm{b}$ & $7.88 \pm 0.46(90) \mathrm{c}$ & $4.47 \pm 0.62(21) \mathrm{ab}$ & $55.82^{*}(\mathrm{p}<0.000)$ \\
Sapling & $30.5 \pm 1.9(23) \mathrm{a}$ & $39.8 \pm 5.5(6) \mathrm{a}$ & $36.50 \pm 2.67(20) \mathrm{a}$ & - & $2.57(\mathrm{p}<0.087)$ \\
Adult & $270.5 \pm 171.0(4) \mathrm{a}$ & $115.9 \pm 15.0(8) \mathrm{a}$ & $183.5 \pm 20.1(19) \mathrm{a}$ & $223.3 \pm 30.5(13) \mathrm{a}$ & $1.59(\mathrm{p}<0.206)$ \\
\hline
\end{tabular}

The $F$-test marked values indicate significant difference between means of each group. Along each line means followed by the same letter indicate no significant differences according to Spojtvoll/Stoline Tukey's tests $(\mathrm{p}<0.05)$.

damage; $17.5 \%$ of its seedlings died during the study period (1996-1997). Trampling by cattle and sand burial were possibly the main mortality causes in the understory. The sub-populations on large and less impacted fragment sites (CF and EF) apparently showed lower or absent mortality.

\section{Whole-population patterns}

The matrix analysis for one-year population dynamics after a reproductive event shows that more than $83 \%$ of individuals stay in the same class. Mortality was observed for seedling 1 and 2, sapling and adult (only one) classes. Therefore, only a few transitions to the next class were observed (1-2\%), concentrated mostly in small individuals belonging to the first three classes. Regressions to smaller classes were noticed only for seedling $2(1 \%)$ and subsapling (3\%) classes. A small adult and an adult respectively contribute with approximately 82 and 118 new seedlings for each year. Population growth rate was about $\lambda=1.0211$, indicating a small tendency to expand (Fig. 2). Mechanical injury patterns also suggested that densitydependent effects were small or absent, while mechanical impacts from anthropogenic sources were more frequent (Table 1).

\section{Discussion}

The Caesalpinia echinata population studied within fragments of various sizes tends to expand by a rate of $2 \%$ after a reproductive event. This is quite surprising given the intensity of human induced fragmentation and overexploitation of local populations since the 1500 s. This seems to suggest that small adults and poles were not logged in the past, while large trunks were exported to Europe (Dean 1996). Like other long-lived tropical tree species, individuals stay for a long time in the same class with few transitions (Silvertown $e t$ al. 1993). Population growth rate is near one corroborating the species slow growth as expected for hardwood trees. Small growth rates were also observed in tropical rain forest tree species (Silvertown et al. 1993; AlvarezBuylla 1994). Surprisingly, during the study period, we noticed one adult death, a very rare event in long-lived tree studies (Primack 1985), but we cannot know if this was due to senility or some local impact.

On the other hand, sub-populations varied in their response to fragment size and impact. Three sub-populations were subjected to considerable edge effect, and had in common a higher proportion of seedlings, as compared to saplings and adults. This was in contrast to the more similar proportion of seedlings and adults shown by the sub-population at the centre of the large fragment, away from direct edge effect. Laurance et al. (1998) suggest that edge effects may influence positively some recruitment rates, which in the case of C. echinata may be due to the higher light availability of the edge sites. Germination and early growth under cultivation (Aguiar \& Barbedo 1996) and ecophysiological performance of adults in field conditions (Geßler et al. 2005) are favoured by higher light intensities. As 


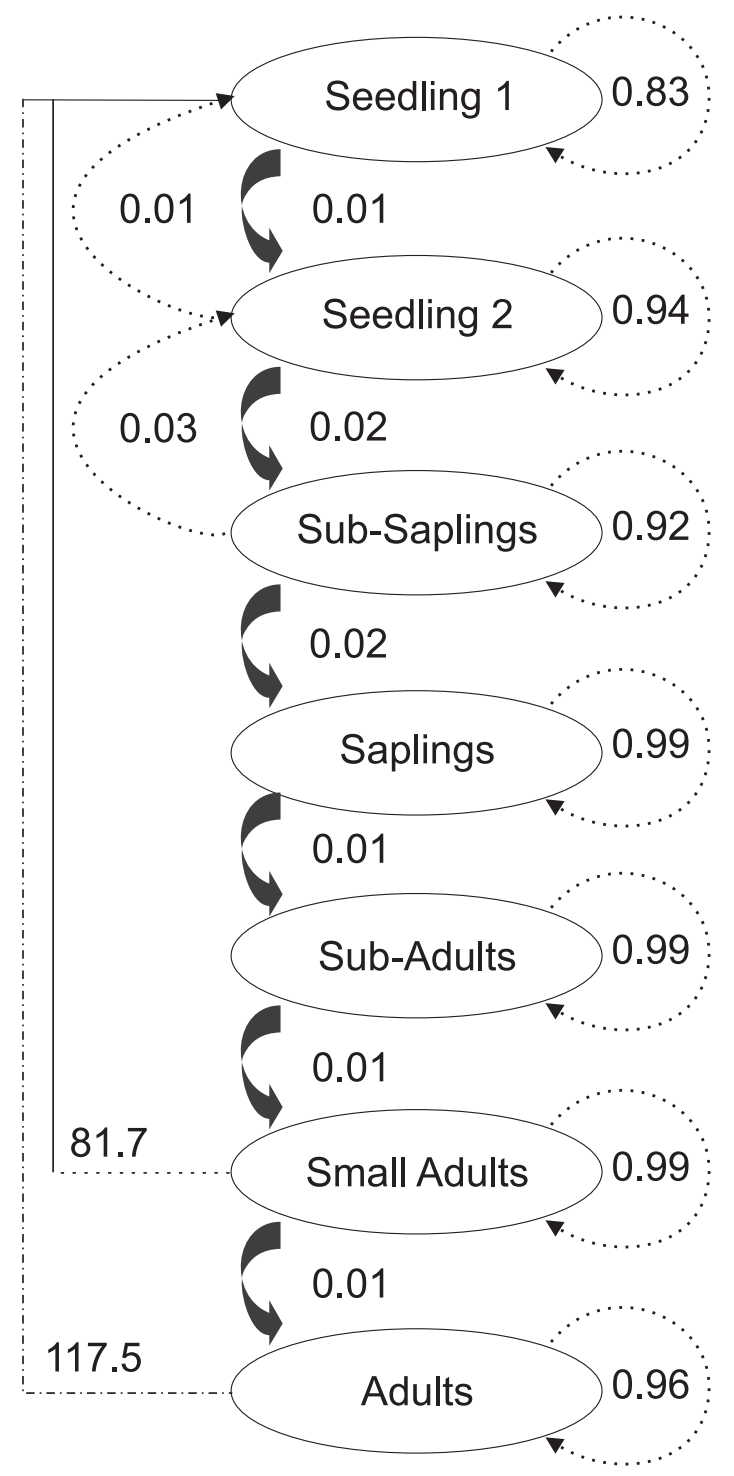

Figure 2 - Life cycle graph and estimated transition rates for the Cabo Frio region whole-population of Caesalpinia echinata Lam. (Brazilwood). Dominant eigenvalue $\lambda=1.0211$ indicating that populations are expanding. Curved block arrows indicate transition to next class. A solid line indicates fecundity (seedlings produced per individual in a year). A small dotted line indicates regression to previous class and large dotted lines indicate stasis in the same class

observed by Rincón \& Huante (1993), other Caesalpinia species also acclimate to a wide variety of light environments.

The high recruitment rates of $C$. echinata at forest edges may be an indication that success under shade could be related to gap formation. The fact that this emergent, long-lived tree is dominant in these semideciduous forests could be related to higher light availability in the understory during the dry season. These results are in agreement with Cunha \& Lima (1992) who suggested that this species is a relict of old seasonal semideciduous forests, which were widespread in the drier periods of the Pleistocene.

However, there seems to be a considerable environmental sieve operating at the transition from seedling to sapling stage. This was particularly evident in the sub-population at CF, where saplings were totally absent, probably due to long periods of little or no seedling recruitment (Fenner 1985), and at the more impacted fragments (SF and HF), where seedling density was very high and the proportional individual loss from one stage to the other was higher, probably due to high man-made impact (see Laurance 2000). Supporting this, when we consider the whole population patterns, only those classes show size regressions (Fig. 1).

The fact that adult proportion in relation to seedling number was lower in the more impacted fragments (SF and HF) suggests that their reproductive value is higher. This is more evident in SF that had the largest adult plant. Larger plants tend to exhibit greater reproductive values (Horvitz \& Schemske 1995; Weiner 1988), which implies sub-population differences in fecundity (see Küppers 1994).

In spite of whole population patterns indicating population regeneration and expansion, sub-populations with few fecund adults (e.g., SF) may decline faster if these individuals die (Condit et al. 1998). Additionally, large seedling stands, as in SF, may represent an important source of genetic diversity (Sarukhán 1980). In the case studied here, the sub-population with more seedlings (858) and saplings (23) is also the one with fewer adults (4), and was located at the smallest, most impacted fragment. Thus, although this fragment had only 0.2 ha, its conservation seems of utmost importance in this area; if this fragment is excluded, the whole-population potentially declines leading to local species extinction. Furthermore, a genetic study 
involving the same set of sub-populations investigated here (Cardoso et al. 1998; Cardoso et al. 2005) pointed to a considerable within-population genetic diversity in the Cabo Frio region and that the sub-populations studied are actually one genetic population with gene flow between them. Therefore, conservation initiatives for this threatened species, and possibly of the coastal plain forests of Brazil as a whole, should consider the relevance of small-sized fragments.

\section{ACKNOWLEDGEMENTS}

We thank D. S. D. Araujo, A. F. Costa, M. T. Nascimento and one anonymous reviewer for critical reading of the manuscript; several students of the Plant Ecology Laboratory for field assistance; and C. de la Maria and the Instituto Búzios Mata Atlântica/Búzios Bauen Club for providing logistic facilities. The Brazilian Research (CNPq) and Education (CAPES) Councils provided research grants.

\section{REFERENCES}

Alvarez-Buylla, E. R. 1994. Density dependence and patch dynamics in Tropical Rain Forests: Matrix Models and applications to a tree species. The American Naturalist 143: 155-191.

Aguiar, F. F. \& Barbedo, C. J. 1996. Efeito de fatores ambientais no crescimento de mudas de pau-brasil (Caesalpinia echinata Lam.). RBHO 2: 26-32.

Araujo, D. S. D. 1997. Cabo Frio region, southeastern Brazil. In: Davis, S. D.; Heywood, V. H.; Herrera-Macbryde, O.; Villa-Lobos, J. \& Hamilton, A. C. (eds.). Centers of plant diversity: a guide and strategy for their conservation. 3. The Americas. WWF/IUCN, Washington. Pp. 373-375.

Benitez-Malvido, J. 1998. Impact of forest fragmentation on seedling abundance in a tropical rain forest. Conservation Biology 12: 380-389.

Brasil 1992. Portaria no: 006/92-N, 15 de janeiro de 1992. Lista oficial de espécies da flora brasileira ameaçadas de extinção. Diário
Oficial da República Federativa do Brasil, Brasília-DF.

Bruna, E. M.; Nardy, O.; Strauss, S. Y. \& Harrison, S. 2002. Experimental assessment of Heliconia acuminata growth in a fragmented Amazonian landscape. Journal of Ecology 90: 639-649.

Cardoso, M. A.; Provan, J.; Powell, W.; Ferreiras, P. C. E. \& Oliveira, P. E. 1998. High genetic differentiation among remnant populations of the endangered Caesalpinia echinata Lam. (Leguminosae-Caesalpinoideae). Molecular Ecology 7: 601-608.

Cardoso, S. R. S.; Provan, J.; Lira, C. F.; Pereira, L. O. R.; Ferreira, P. C. G. \& Cardoso, M. A. 2005. High levels of genetic structuring as a result of population fragmentation in the tropical tree species Caesalpinia echinata Lam.. Biodiversity and Conservation 14: 1047-1057.

Caswell, H. 1989. Matrix Population Models: Construction, Analysis, and Interpretation, Sinauer Associates, Sunderland, MA.

Condit, R.; Hubbell, S. P. \& Foster, R. B. 1995. Mortality rates of 205 neotropical tree and shrub species and the impact of a severe drought. Ecological Monographs 65: 419-439. ; Sukumar, R.; Hubbell, S. P. \& Foster, R. B. 1998. Predicting population trends from size distributions: a direct test in a tropical tree community. American Naturalist 152: 495-509.

Corrêa, M. P. 1974. Dicionário das plantas úteis do Brasil e das exóticas cultivadas. IBDF, Ministério da Agricultura, Rio de Janeiro.

Cunha, M. W. \& Lima, H. C. 1992. Viagem à Terra do Pau-Brasil. Agência Brasileira de Cultura, Rio de Janeiro.

Dean, W. 1996. A ferro e fogo: a história e a devastação da Mata Atlântica brasileira. Companhia das letras, São Paulo.

Didham, R. K. \& Lawton, J. H. 1999. Edge structure determines the magnitude of changes in microclimate and vegetation structure in tropical forest fragments. Biotropica 31: 17-30. 
Ehrlén, J. \& van Groenendael, J. 1998. Direct perturbation analysis for better conservation. Conservation Biology 12: 470-474.

FEEMA (Fundação Estadual do Meio Ambiente). 1988. Importância da biota da região de Cabo Frio, Rio de Janeiro.

Fenner, M. 1985. Seed Ecology. Chapman and Hall, London.

Fahrig, L. 2003. Effects of habitat fragmentation on biodiversity. Annual Review of Ecology and Systematics 34: 487-515.

Geßler, A.; Duarte, H. M.; Franco, A. C.; Lüttge, U.; Mattos, E. A.; Nahm, M.; Rodrigues, P. J. F. P.; Scarano, F. R. \& Rennenberg, H. 2005. Ecophysiology of selected tree species in different plant communities at the periphery of the Atlantic Forest of SE-Brazil. III. Three legume trees in a semideciduous dry forest. Trees - Structures and Function 19: 523-530.

Hanski, I. \& Gilpin, M. 1991. Metapopulation dynamics: brief history and conceptual domain. Biological Journal of the Linnaean Society 42: 3-16.

Harper, K. A.; Macdonald S. E.; Burton, P. J.; Chen, J.; Brosofske, Saunders, S.C.; Euskirchen, E. S.; Roberts, D.; Jaiteh, M. S. \&, Esseen, P. 2005. Edge influence on forest structure and composition in fragmented landscapes. Conservation Biology 19: 768-782.

Horvitz, C. C. \& Schemske, D. W. 1995. Spatiotemporal variation in demographic transitions of a tropical understory herb: projection matrix analyses. Ecological Monographs 65: 155-192.

Janzen, D. H. 1983. No park is an island: increase in interference from outside as park size decreases. Oikos 41: 402-410.

Krebs, C. J. 1989. Ecological methodology. Harper-Collins Publishers, New York, $654 \mathrm{p}$.

Küppers, M. 1994. Canopy gaps: competitive light interception and economic space filling-a matter of whole-plant allocation. In: Caldwell, M. M. \& Pearcy, R.W. (eds.). Exploitation of environmental heterogeneity by plants. Academic Press, London. Pp. 111-144.

Laurance, W. F. 2000. Do edge effects occur over large spatial scales? Trends in Ecology and Evolution 15: 134-135.

; Ferreira, L. V.; Rankin de Merona, J. M.; Laurance, S. G.; Hutchings, R. W. \& Lovejoy, T. E. 1998. Effects of fragmentation on recruitment patterns in Amazonian tree communities. Conservation Biology 12: 460-469.

; Laurance, S. G.; Ferreira, L. V.; Rankin de Merona, J. M.; Gascon, C. \& Lovejoy, T. E. 1997. Biomass collapse in Amazonian forest fragments. Science 278: 1117-1118.

; Lovejoy, T.; Vasconcelos, H. L.; Bruna, E. M.; Didham, R. K.; Stouffer, P.; Gascon, C.; Bierregaard, R.; Laurance, S. \& Sampaio, E. 2002. Ecosystem decay of Amazonian forest fragments, a 22-year investigation. Conservation Biology 16(3): 605-618.

; Nascimento, H. E. M.; Laurance, S. G.; Andrade, A.; Ewers, R. M.; Harms, K. E.; Luizão, R. C. C. \& Ribeiro, J. E. 2007. Habitat fragmentation, variable edge effects, and the landscape-divergence hypothesis. PLoS ONE 2(10): e1017. doi:10.1371/journal.pone.0001017

Lefkovitch L. P. 1965. The study of population growth in organisms grouped by stages. Biometrics 21: 1-18.

Lieberman, D.; Lieberman, M.; Peralta, R. \& Hartshorn, G. S. 1985. Mortality patterns and stand turnover rates in a wet tropical forest in Costa Rica. Journal of Ecology 73: 915-924.

McCook, L. J. 1994. Understanding ecological community succession: causal models and theories, a review. Vegetatio 110: 115-147.

Mooney, H. A.; Bullock, S. H. \& Medina, E. 1995. Introduction. In: Bullock, S. H.; Mooney, H. A. \& Medina, E. (eds.). Seasonally dry tropical forests. Cambridge University Press, New York. Pp. 1-8. 
Morris, W. F. \& Doak, D. F. 2002. Quantitative conservation biology: theory and practice of population viability analysis. Sinauer Associates, Sunderland, MA, USA.

Myers N.; Mittermeier, R. A.; Mittermeier, C. G.; Fonseca, G. A. B. \& Kent, J. 2000. Biodiversity hotspots for conservation priorities. Nature 403: 853-858.

Oliveira-Filho, A. T.; Mello, J. M. \& Scolforo, J. R. 1997. Effects of past disturbance and edges on tree community structure and dynamics within a fragment of tropical semideciduous forest in a south-eastern Brazil over a five-year period (1987-1992). Plant Ecology 131: 45-66.

Oliveira-Filho, A. T. \& Fontes, M. A. L. 2000. Patterns of floristic differentiation among Atlantic forests in southeastern Brazil and the influence of climate. Biotropica 32: 793-810.

Primack, R. B.; Ashton, P. S.; Chai, P. \& Lee, H. S. 1985. Growth rates and population structure of Moraceae trees in Sarawak, East Malaysia. Ecology 66: 577-588.

Rincón, E. \& Huante, P. 1993. Growth responses of tropical deciduous tree seedlings to contrasting light conditions. Trees Structure and Function 7: 202-207.

Sanchez-Azofeifa, G. A.; Kalacska, M.; Quesada, M.; Calvo-Alvarado, J. C.; Nassar, J. M. \& Rodríguez, J. P. 2005. Need for integrated research for a sustainable future in tropical dry forests. Conservation Biology 19: 285-286.

Sarukhán, J. 1980. Demography problems in tropical systems. In: Solbrig, O. T. (ed.). Demography and evolution in plant populations. Blackwell, Oxford. Pp. 161-188.

Scarano, F. R. 2002. Structure, function and floristic relationships of plant communities in stressful habitats marginal to the Brazilian Atlantic rain forest. Annals of Botany 90: 517-524.

; Duarte, H. M.; Ribeiro, K. T.; Rodrigues, P. J. F. P.; Barcellos, E. M. B.; Franco, A. C.; Brulfert, J.; Deléens, E. \& Lüttge, U. 2001. Four sites with contrasting environmental stress in southeastern Brazil: relations of species, life form diversity, and geographical distribution to ecophysiological parameters. Botanical Journal of Linnaean Society 136: 345-364.

Schemske, D. W.; Husband, B. C.; Ruckelshaus, M. H.; Goodwillie, C.; Parker, I. M. \& Bishop, J. G. 1994. Evaluating approaches to the conservation of rare and endangered plants. Ecology 75: 584-606.

Sih, A.; Jonsson, B. G. \& Luikart, G. 2000. Habitat loss: ecological, evolutionary and genetic consequences. Trends in Ecology and Evolution 15: 132-134.

Silvertown, J.; Franco, M.; Pisanty, I. \& Mendoza, A. 1993. Comparative plant demography relative importance of life-cycle components to the finite rate of increase in woody and herbaceous perennials. Journal of Ecology 81: 465-476.

Sokal, R. R. \& Rohlf, F. J. 1995. Biometry: the principles and practice of statistics in biological research. $3^{\text {rd }}$ ed. Freeman, New York.

Weiner, J. 1988. Variation in performance of individuals in plant populations. In: Davy A. J.; Hutchings M. J. \& Watkinson A. R. Plant population ecology. Blackwell, Oxford. Pp. 59-81.

Williams-Linera, G. 1990. Vegetation structure and environmental conditions of forest edges in Panama. Journal of Ecology 78: 356-373. 